\title{
Chemical composition, energy value for chickens, and protein utilization in rats of rapeseed expeller cakes produced by different pressing technologies
}

\section{Stefania Smulikowska, Barbara Pastuszewska, Anna Mieczkowska and Anna Ochtabińska}

\author{
The Kielanowski Institute of Animal Physiology and Nutrition, \\ Polish Academy of Sciences \\ 05-110 Jablonna, Poland
}

(Received 4 September 1996; accepted 6 February 1997)

\begin{abstract}
The chemical composition, glucosinolate, total and available lysine contents were determined in seven rapeseed ,00" expeller cakes and one solvent meal. Five cakes were produced using a 02 ZVO press from seeds heated to $40-50^{\circ} \mathrm{C}$ (REM), one cake using a Rosedown press from seeds heated to over $80^{\circ} \mathrm{C}$ (REC No. 6), and one was an industrially prepressed cake from seeds heated to over $80^{\circ} \mathrm{C}$ (REC No. 7). The fat content in the cakes ranged from 10.3 to $23.2 \% \mathrm{DM}$. The glucosinolate content in the cakes ranged from 13.4 to $55.1 \mathrm{mM} / \mathrm{g}$ FFDM and was close to that in raw seeds when compared on a fat-free DM basis.

Energy value $\left(\mathrm{AME}_{\mathrm{N}}\right.$ ) of REM cakes and REC No. 7 determined on chicken varied widely (8.55 to $14.60 \mathrm{MJ} / \mathrm{kg} \mathrm{DM}$ ) and was positively correlated with their fat content. Biological value (BV) of protein of four REM, two REC and solvent meal determined in rats varied from 80.1 to 96.7 , despitc rather uniform total and available lysine contents. BV, feed intake and weight gain of rats fed on REM tended to decrease while relative thyroid weight tended to increase as the glucosinolate content in cakes rose.

It is concluded that the nutritional value of rapeseed expeller cakes produced from mildly heated seeds may vary considerably, the main factor affecting $A M E_{\mathrm{\Lambda}}$ being fat content, while that affecting protein value being the glucosinolate content.
\end{abstract}

KEY WORDS: rapeseed expeller cake, glucosinolates, lysine, energy, protein utilization 


\section{INTRODUCTION}

Recent interest in expelling oil from double-low rapeseed has been stimulated by the need for a more cost effective technology than prepressing/solvent extraction, and also by the higher energy value of expeller cakes than solvent extracted meals. The nutritional value of rapeseed cakes depends on the quality of seeds, particularly on the level of glucosinolates, and on the technology of expelling, which may affect myrosinase activity, glucosinolate, and total and available lysine contents.

Increasing amounts of double-low rapeseed grown in Poland are processed in small rural mills equipped with screw press expellers (Podkówka and Podkówka, 1993; Podkówka et al., 1994). The effects of introducing rapeseed 00 expeller cakes to poultry and pig diets were investigated by several authors (Kinal et al., 1990; Smulikowska et al., 1990; Tywończuk et al., 1994; Frankiewicz et al., 1995), little is known, however, about the variability of their composition and nutritional value. According to Podkówka et al. (1994) the fat content in 12 samples of rapeseed 00 expeller cake produced over a several-month period using the same press was rather uniform $(12-15 \% \mathrm{DM})$, while the content of other components varied to a small extent depending on the degree of oil removal.

The present study was undertaken to assess the variability of the chemical composition, glucosinolate content and nutritional value of rapeseed 00 expeller cakes produced on screw expellers from mildly heated seeds (REM), and to compare them with the cakes produced from rape seeds heated to over $80^{\circ} \mathrm{C}$ (cooked) prior to pressing (REC). Mctabolizable energy value of expeller cakes was determined in chickens, while their protein value was assayed in rats.

\section{MATERIAL AND METHODS}

\section{Material}

Seven samples of expeller cakes and one sample of solvent extracted meal (RSM) produced from 00-type rape seed of unknown varieties were evaluated.

Five samples (REM No.1 to 5) were manufactured in small rural mills using the 02 ZVO type screw press expeller of Polish production. Prior to pressing, the seeds were mildly heated to $40-50^{\circ} \mathrm{C}$ (Podkówka and Podkówka, 1993), the temperature during pressing was about $75^{\circ} \mathrm{C}$ (personal information).

Two cakes (REC No. 6 and No. 7) were produced from seeds cooked with steam to a higher temperature. REC No. 6 was manufactured from seeds heated for $90 \mathrm{~min}$ at temperatures increasing from $60^{\circ} \mathrm{C}$ to $100-105^{\circ} \mathrm{C}$ (unpublished data) and next pressed on a Rosedown type screw expeller (de Smet technology). REC 
No.7 was an industrially prepressed cake from seeds heated to over $80^{\circ} \mathrm{C}$, while solvent meal (RSM) was produced by industrial extraction of REC No. 7 followed by toasting.

\section{Experiment on chickens}

Samples of REM No. 1 to 5 and the REC No. 7 were evaluated. Apparent metabolizable energy value corrected for zero $N$ balance $\left(A M E_{N}\right)$ and apparent digestibility of nutrients were determined on 4-week-old broiler cockerels (Starbro) with a mean initial body weight of $774 \mathrm{~g}$. The birds were housed individually in balance cages, 10 birds per treatment, and were fed a cold pelleted basal diet (Table 3) or diets containing $60 \%$ of basal diet and $40 \%$ of ground expeller cakes combined on a DM basis. All the diets contained $0.3 \% \mathrm{Cr}_{2} \mathrm{O}_{3}$ as a marker. The diets were fed at the level of $90 \mathrm{~g} / \mathrm{bird} /$ day, in three meals. After two days of preliminary feeding the birds were fasted during $14 \mathrm{~h}$ then fed on the same diets for 3 days, and fasted for $14 \mathrm{~h}$. Feed intake was recorded during the whole time, while during last $86 \mathrm{~h}$ of the experiment, excreta were collected, frozen, kept at $-18^{\circ} \mathrm{C}$, and freeze-dried for analysis.

\section{Experiment on rats}

Four samples (No. 1 to 4) of REM, REC No. 6 and No. 7, and solvent extracted meal (RSM-sample No. 8) from the same processing as cake No. 7 were evaluated. The semisynthetic diets contained the expeller cakes or RSM as the only source of protein at a level corresponding to $9.5 \% \mathrm{CP}$. Crude fat content was equalized in all diets to $7.3 \%$ by addition of rape seed oil, and crude fibre content to $4.6 \%$ by addition of cellulose. The diets were supplemented with minerals according to NRC (1976) and vitamins according to AOAC (1975), $12 \%$ sucrose and wheat starch to 100 per cent.

True digestibility (TD) and biological value (BV) of protein were determined according to the Thomas-Mitchell method in a balance experiment performed on 29-day-old male outbred $\mathrm{IF}_{\%}$ JAZ rats with mean initial body weight $78 \mathrm{~g}$, seven animals per treatment. The rats were housed individually in balance cages and were fed $11 \mathrm{~g}$ of experimental diets per day during 10 days. Feed intake was recorded, and faeces and urine were collected during the last 6 days. TD and BV were corrected for metabolic and endogenous urinary $\mathrm{N}$, respectively, according to Lehman et al. (1968). Net protein utilization (NPU = BVxTD) and utilizable protein (NPV $=$ NPUxCP content, $\%)$ values were calculated.

Growth performance was assayed on 25-day-old male outbred rats with mean initial body weight $59 \mathrm{~g}$, seven animals per treatment. The animals were fed on the diets ad libitum during 21 days, feed intake and body weight were recorded 
weekly. At the conclusion of the experiment the animals were killed, the livers and thyroids were excised and immediately weighed.

\section{Chemical and statistical analysis}

Chemical composition of expeller cakes, chick diets and excreta, and $\mathrm{N}$ content in rat diets, faeces and urine were determined by standard methods (AOAC, 1994). NDF and ADF content in cakes and meal were determined according to Van Soest (1967) on a Fibertec M (Tecator) apparatus, glucosinolates were determined by HPLC according to the ISO-9167 method (1991). Total lysine was assayed using a type 6300 Beckman Analyzer, while available lysine by the method of Booth (1971). In chicken excreta, crude fat was determined by ethyl ether extraction without acid hydrolysis, faecal $\mathrm{N}$ by Ekman et al. (1949). Gross energy of cakes, chick diets and excreta was measured on a Perr adiabatic oxygen bomb calorimeter KL-10, chromic oxide was determined spectrophotometrically following wet ashing according to the procedure described by Hinsberg et al. (1953). Apparent digestibility of nutrients and $A M E_{N}$ value of the diets were calculated relative to the ratio of $\mathrm{Cr}_{2} \mathrm{O}_{3}$ to the content of gross energy or nutrient in question in food and droppings. $\mathrm{AME}_{\mathrm{N}}$ was corrected to zero nitrogen balance using $1.96 \mathrm{MJ} / \mathrm{g}$ nitrogen retained (Hill and Anderson, 1958). $A M E_{N}$ and the apparent digestibility of crude protein, crude fat and NFE of cakes was calculated from the difference between respective values of basal and experimental diets according to Campbell et al. (1983) and Pesti and Ware (1986). Experimental $\mathrm{AME}_{\mathrm{N}}$ values were compared with values calculated from chemical composition using formulas for rapeseed expeller meal according to European Table of Energy Values for Poultry Feedstuffs (1989).

The results were subjected to one way analysis of variance. The significance of differences among groups was estimated by the Duncan multiple range test using „Statgraphics Plus” ver. 7 software.

\section{RESULTS}

\section{Chemical composition}

The chemical composition of rapeseed expeller cakes and RSM is given in Table 1 while their glucosinolate and lysine contents in Table 2 . Fat content varied from 10 to $15 \% \mathrm{DM}$ in four samples of REM and in REC, while it exceeded $21 \%$ DM in REC from the oil factory (No. 7) and in REM No. 4. Protein content was lower than in the RSM and was slightly greater in the expeller cakes having a lower fat level. Crude fibre content varied from 10.8 to 
TABLE 1

Chemical composition of rapeseed press cakes and solvent meal, \% DM

\begin{tabular}{rccccccc}
\hline Product & DM, \% & Protein & $\begin{array}{c}\text { Ether } \\
\text { extract }\end{array}$ & $\begin{array}{c}\text { Crude } \\
\text { fibre }\end{array}$ & NFE & ADF & NDF \\
\hline Cake REM 1' & 92.51 & 34.0 & 10.3 & 11.8 & 36.8 & 18.4 & 20.7 \\
REM 2 & 92.31 & 31.5 & 14.3 & 11.8 & 35.7 & 18.8 & 20.6 \\
REM 3 & 92.29 & 31.0 & 14.8 & 12.6 & 34.9 & 18.5 & 20.0 \\
REM 4' & 91.70 & 30.0 & 23.2 & 10.8 & 30.4 & 14.7 & 17.5 \\
REM 5 & 90.88 & 32.2 & 14.5 & 12.3 & 34.5 & 18.3 & 19.6 \\
REC 6 & 95.61 & 32.3 & 13.0 & 15.5 & 32.4 & 21.3 & 29.6 \\
REC 7 & 92.07 & 28.7 & 21.2 & 10.5 & 33.8 & 21.6 & 24.8 \\
Meal RSM 8 & 89.56 & 36.8 & 3.9 & 12.8 & 40.8 & 23.2 & 33.8 \\
\hline
\end{tabular}

1 seeds mildly heated and pressed with 02 ZVO press

${ }^{2}$ seeds cooked and pressed with „Rosedowns" press

${ }^{3}$ seeds cooked and prepressed from standard processing in oil factory

${ }^{4}$ solvent extracted and toasted meal

$15.5 \%$ DM. Total lysine content in all expeller cakes ranged between 5.90 to $6.41 / 16 \mathrm{~g} \mathrm{~N}$ and was higher than in RSM $(5.26 \mathrm{~g} / 16 \mathrm{~g} \mathrm{~N})$. Available lysine content was rather uniform in the cakes except cake No. $5(4.76 \mathrm{~g} / 16 \mathrm{~g} \mathrm{~N})$, it was also lower in the RSM $(4.42 \mathrm{~g} / 16 \mathrm{~g} \mathrm{~N})$. The glucosinolate content in REM samples varied from 13.4 to $30.4 \mathrm{mM} / \mathrm{g}$ fat free DM (Table 2), it was the highest in the REC and RSM from the oil factory (55.1 and $42.3 \mathrm{mM} / \mathrm{g}$ fat free DM, respectively).

TABLE 2

Glucosinolates, and total and available lysine conients in rapeseed products

\begin{tabular}{|c|c|c|c|c|c|c|}
\hline \multirow{3}{*}{ Product } & \multicolumn{4}{|c|}{ Glucosinolates } & \multicolumn{2}{|c|}{ Lysine, g/16g N } \\
\hline & \multicolumn{2}{|c|}{$\mathrm{mM} / \mathrm{gDM}$} & \multicolumn{2}{|c|}{$\mathrm{mM} / \mathrm{gFFDM}$} & \multirow{2}{*}{ total } & \multirow{2}{*}{ available } \\
\hline & cakes & seeds & cakes & seeds & & \\
\hline Cake REM $1^{1}$ & 15.5 & 8.3 & $18.9(112)^{x}$ & 16.9 & 6.40 & 5.29 \\
\hline REM $2^{1}$ & 16.6 & 11.6 & $21.3(89)$ & 23.8 & 6.33 & 5.06 \\
\hline REM $3^{\prime}$ & 23.6 & 17.0 & $30.4(84)$ & 36.4 & 6.41 & 5.30 \\
\hline REM 4' & 23.2 & 18.6 & $33.9(92)$ & 36.5 & 6.24 & 5.28 \\
\hline REM $5^{1}$ & 10.2 & nd & 13.4 & nd & 6.16 & 4.76 \\
\hline $\operatorname{REC} 6^{2}$ & 24.4 & nd & 29.5 & nd & 6.22 & 5.25 \\
\hline $\operatorname{REC} 7^{3}$ & 39.1 & 23.3 & $55.1(112)$ & 49.1 & 5.90 & 5.07 \\
\hline Meal RSM $8^{4}$ & 36.2 & 23.3 & $42.3(86)$ & 49.1 & 5.26 & 4.42 \\
\hline
\end{tabular}

$1,2,3,4$ - as in table 1

nd - non determined

${ }^{x}$ - percent of content in the seeds 
TABLE 3

Composition of basal diets, in \%. Experiment on chicken

\begin{tabular}{lc}
\hline Ingredients & $\%$ \\
\hline Soyabcan meal & 28.0 \\
Wheat & 67.7 \\
Calcium carbonate & 1.4 \\
Dicalcium phosphate & 1.6 \\
$\mathrm{NaCl}$ & 0.6 \\
Vitamin-mineral premix* & 0.7
\end{tabular}

* supplied per kilogram of diet: vit. A $14000 \mathrm{IU}$; vit. $\mathrm{D}_{3} 2800 \mathrm{IU}$; vit. E $21 \mathrm{mg}$; vit. $\mathrm{K} 2.8 \mathrm{mg}$; vit. $\mathrm{B}_{\text {; }} 1.4$ mg; vit. $B_{2} 5.6 \mathrm{mg}$; vit. $B_{6} 2.8 \mathrm{mg}$; vit. $B_{12} 0.0168 \mathrm{mg}$; niacin $21 \mathrm{mg}$; pantothenic acid $14 \mathrm{mg}$; folic acid $0.7 \mathrm{mg}$; biotine $0.07 \mathrm{mg}$; choline $280 \mathrm{mg}$; Mn $84 \mathrm{mg}$; Zn $70 \mathrm{mg}$; Fe $28 \mathrm{mg}$; Cu $8.4 \mathrm{mg}$ J $0.56 \mathrm{mg}$; Se $0.21 \mathrm{mg} ;$ Co $0.28 \mathrm{mg}$

Glucosinolate content expressed on DM basis was higher in cakes than in unprocessed seeds from which the cakes were produced, however, if expressed on a fat-free dry matter (FFDM) basis, the average content of glucosinolates in the expeller cakes was from 84 to $112 \%$ of that in the seeds, the observed differences were rather the effect of analytical error.

\section{Digestibility of nutrients and metabolizable energy for chickens}

The digestibility of crude protein, crude fat and NFE varied to great extent among the cakes (Table 4), and was the greatest in REM No. 4 (83.0, 83.1 and $68.3 \%$, respectively) and the lowest in REM No. $5(69.5,72.7$ and $37.1 \%$ respectively), which had also the lowest available lysine content (Table 2).

The digestibility of nutrients affected the metabolizable energy value determined with chickens $\left(\mathrm{AME}_{\mathrm{N}} \mathrm{e}\right.$ ) which varied from $8.55 \mathrm{MJ} / \mathrm{kg} \mathrm{DM}$ in REM No. 5 to $14.60 \mathrm{MJ} / \mathrm{kg} \mathrm{DM}$ in REM No. 4. AME $\mathrm{E}_{\mathrm{v}}$ of the cakes was positively correlated with their fat contents $(r=0.82 ; \mathrm{P} \leqslant 0.05)$.

The metabolizable energy content calculated from the chemical composition of cakes according to the equations given in the European Table of Energy Values of Poultry Feedstuffs (1989) varied from 9.83 to $13.43 \mathrm{MJ} / \mathrm{kg} \mathrm{DM}$ and was positively correlated with experimental values $(r=0.85 ; \mathrm{HP} \leqslant 0.05)$. The greatest discrepancy between experimental and calculated values was found in cakes differing in nutrient digestibility, in REM No. $4 \mathrm{AME}_{\mathrm{N}} \mathrm{e}$ being $1.17 \mathrm{MJ} / \mathrm{kg}$ $\mathrm{DM}$ higher while in REM No. 5-2.27 MJ/kg DM lower than respective values calculated from chemical composition, the standard deviation for the last value was considerably greater than average.

Utilization of gross energy $\left(\Lambda \mathrm{ME}_{\mathrm{N}} / \mathrm{EB}\right.$ ratio) varied from 38 to $60 \%$. 
TABLE 4

Apparent digestibility of crude protein (CP), crude fat (CF) and NFE, AME $(\mathrm{MJ} / \mathrm{kg} \mathrm{DM})$ and metabolizability of energy ( $\mathrm{AME}_{\mathrm{N}} \mathrm{e} / \mathrm{GE}$ in \%), in evaluated rapeseed expeller cakes. Experiment on chickens

\begin{tabular}{|c|c|c|c|c|c|c|}
\hline \multirow{2}{*}{ Product } & \multicolumn{3}{|c|}{ Apparent digestibility, $\%$} & \multirow{2}{*}{$A M E_{N} \pm S D$} & \multirow{2}{*}{$A M E_{N} c$} & \multirow{2}{*}{$\begin{array}{c}\mathrm{AMF}_{\mathrm{N}} \mathrm{e} / \mathrm{GE} \\
\%\end{array}$} \\
\hline & $\mathrm{CP}$ & CF & NFE & & & \\
\hline REM 1 & $76.6^{\mathrm{cdC}}$ & $77.4^{\mathrm{abAB}}$ & $47.7^{\wedge}$ & $9.84 \pm 0.81$ & 9.83 & $45.7^{\mathrm{bB}}$ \\
\hline REM 2 & $71.6^{\mathrm{ab} \wedge \mathrm{B}}$ & $74.6^{\mathrm{aA}}$ & $41.4^{\AA}$ & $9.77 \pm 0.64$ & 10.82 & $43.3^{\mathrm{b} \wedge \mathrm{B}}$ \\
\hline REM 3 & $78.6^{\mathrm{dCD}}$ & $74.4^{\mathrm{aA}}$ & $42.0^{A}$ & $11.83 \pm 0.73$ & 10.87 & $52.9^{\mathrm{cC}}$ \\
\hline REM 4 & $83.0^{\mathrm{cD}}$ & $83.1^{\mathrm{bB}}$ & $68.3^{B}$ & $14.60 \pm 0.64$ & 13.43 & $60.4^{\mathrm{dD}}$ \\
\hline REM 5 & $69.5^{\mathrm{aA}}$ & $72.7^{\mathrm{aA}}$ & $37.1^{\wedge}$ & $8.55 \pm 1.12$ & 10.82 & $38.1^{\mathrm{aA}}$ \\
\hline REC 7 & $74.8^{\mathrm{bcBC}}$ & $75.6^{\mathrm{AAB}}$ & $40.7^{A}$ & $12.37 \pm 0.86$ & 12.62 & $52.8^{\mathrm{cC}}$ \\
\hline SEM & 0.86 & 1.42 & 2.83 & & & 2.13 \\
\hline
\end{tabular}

* $\mathrm{AME}_{\mathrm{N}} \mathrm{e}$ - metabolizable energy value obtained in experiment; $\mathrm{AMF}_{\mathrm{N}} \mathrm{c}$ - metabolizable energy value calculated from chemical composition according to equation after European Table of Energy Values for Poultry Feedstuffs (1989): $\mathrm{AME}_{\mathrm{N}}(\mathrm{kJ} / \mathrm{kg})=13,71 \times \mathrm{CP}+34,94 \times \mathrm{Cr}$ at $+5,543$ $x$ NFE (CP, CFat and NFE in $\mathrm{g} / \mathrm{kg} \mathrm{DM})$

a. b. A, B $-\mathrm{a}, \mathrm{b}-\mathrm{P} \leqslant 0.05 ; \mathrm{A}, \mathrm{B}-\mathrm{P} \leqslant 0.01$

Nutritional value of cake and meal protein for rats

True digestibility of protein of the cakes determined in the experiment on rats was rather uniform (Table 5), the only significant difference was found between the TD of REM No. 1 (85.5) and No. 4 (79.9).

The biological value of REM protein varied from 80 in REM No. 4 to over 96 in REM No. 1 and was negatively correlated with the glucosinolate content in the cakes $(r=-0.90)$, the relationship was not, however, confirmed statistically

TABLE 5

Nutritional value of cake and meal protein for rats

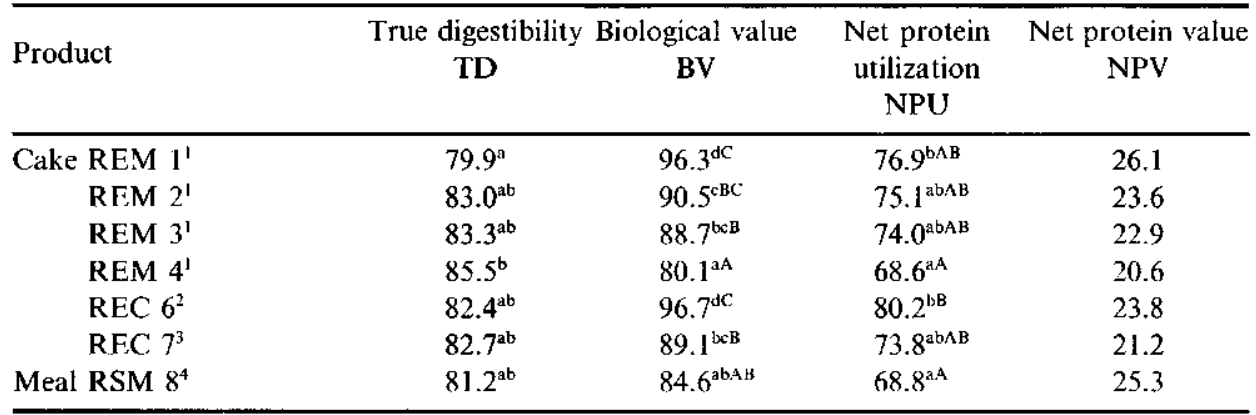

$1,2,3,4$ - as in table 1

a, b. A, B - as in table 4 
TABLE 6

Growth performance of rats fed on cake and meal diets and relative weight of thyroid and liver

\begin{tabular}{rccccc}
\hline Product & $\begin{array}{c}\text { Feed intake } \\
\text { g/21 days }\end{array}$ & $\begin{array}{c}\text { BGW }^{5} \\
\text { g/21 days }\end{array}$ & $\begin{array}{c}\text { FCR }^{6} \\
\text { g feed/g } \\
\text { BWG }\end{array}$ & $\begin{array}{c}\text { Thyroid } \\
\text { mg/100 g } \\
\text { LBW }\end{array}$ & $\begin{array}{c}\text { Liver } \\
\text { g/100 g } \\
\text { LBW }^{7}\end{array}$ \\
\hline Cake REM 1 $^{1}$ & $235.9^{\mathrm{c}}$ & $76.9^{\mathrm{c}}$ & $3.08^{\mathrm{ab}}$ & $12.7^{\mathrm{a}}$ & $6.38^{\mathrm{abc}}$ \\
REM 2 & $189.9^{\mathrm{b}}$ & $49.8^{\mathrm{b}}$ & $3.83^{\mathrm{bcd}}$ & $14.4^{\mathrm{abc}}$ & $6.14^{\mathrm{abc}}$ \\
REM 3 $^{1}$ & $173.4^{\mathrm{ab}}$ & $46.2^{\mathrm{ab}}$ & $3.79^{\mathrm{bc}}$ & $15.1^{\mathrm{abc}}$ & $6.01^{\mathrm{ab}}$ \\
REM 4 $^{1}$ & $145.1^{\mathrm{a}}$ & $32.3^{\mathrm{a}}$ & $4.62^{\mathrm{d}}$ & $20.2^{\text {ad }}$ & $6.78^{\mathrm{bc}}$ \\
REC 6 $^{2}$ & $231.0^{\mathrm{c}}$ & $83.5^{\mathrm{c}}$ & $2.93^{\mathrm{a}}$ & $19.1^{\mathrm{bc}}$ & $6.46^{\mathrm{abc}}$ \\
REC 7 & $184.1^{\mathrm{b}}$ & $54.2^{\mathrm{b}}$ & $3.42^{\mathrm{abc}}$ & $24.8^{\mathrm{d}}$ & $6.81^{\mathrm{c}}$ \\
\hline
\end{tabular}

$1,2,3,4$ - as in table 1

a, $b, A, B$ - as in table 4

${ }^{5}$ body weight gain

${ }^{6}$ feed to $B W G$ ratio

${ }^{7}$ live body weight

because of the small number of samples. BV of protein of REC No. 6 was very high.

Growth performance of rats fed on diets containing the evaluated rapeseed expeller cakes as the protein source varied considerably (Table 6). Among groups fed on REM, feed intake ranged from 145 to $236 \mathrm{~g}$, body weight gain (BWG) during 21 days varied from 32 to $77 \mathrm{~g}$, and feed/gain ratio from 3.08 to $4.62 \mathrm{~g} / \mathrm{g}$ in REM No. 4 and 1,respectively. Feed intake and BWG were negatively correlated with glucosinolate content in REM $(r=-0.92$ and -0.86 , respectively), however, as for BV, significance did not reach the 0.05 level of probability. The rats receiving $\mathrm{REC}$ No. 6 had the greatest $B W G$ and the lowest feed to gain ratio.

Relative thyroid weight in rats fed on REM varied from 12.7 in animals fed on REM No. 1, to $24.8 \mathrm{mg} / 100 \mathrm{~g} \mathrm{LBW}$ in those fed REC from the oil factory. The thyroid weight in rats fed the diet with RSM was significantly lower than of those fed on the respective REC (14.0 vs. $24.8 \mathrm{mg} / 100 \mathrm{~g} \mathrm{BW}$, respectively), despite the rather small difference in glucosinolate content between cake and meal (Table 2).

Relative liver weight did not differ between rats fed on all the expeller cakes, while it was significantly smaller in rats fed on the RSM than on the respective REC (5.97 vs. $6.81 \mathrm{mg} / 100 \mathrm{~g} \mathrm{LBW}$ ).

\section{DISCUSSION}

The range of fat content in the expeller cakes produced by $02 \mathrm{ZVO}$ press $(10.3$ to $23.2 \% \mathrm{DM}$ ) in different small mills was greater than that found by Podkówka 
et al. (1994) in expeller cakes sampled during a several-month using the same press $(12-15 \%$ DM). Fat content in the press cake from the oil factory was high and was very close to the mean fat content in twenty-eight samples of canola press cake from seven oil factories in Canada (Keith and Bell, 1991). The range of oil content reported by these authors was 17.5 to $26.7 \%$, the differences being greater among the factories than among sampling periods.

Fat content in the cakes under study was also greater than the mean value found by Rakowska and Ochodzki (1995) for four cakes of unknown origin $(10.4 \% \mathrm{DM})$. The results of the present study and those of other authors indicate that the fat content in the expeller cakes may be rather variable.

Protein content in the evaluated cakes was lower than average content in the rapeseed 00 meal and tended to be lower in the press cakes with greater fat contents.

The glucosinolate content in two samples of rape seeds processed in rural mills and in the seeds processed in the oil factory exceeded $25 \mathrm{mM} / \mathrm{g}$ fat-free DM considered the upper limit in commercial low glucosinolate rape seeds (Krzymański, 1993). Due to removing part of the oil, the glucosinolate content in DM of expeller cakes was higher than in the respective sceds. This agrees with the data reported by Schöne (1995) that glucosinolate content on dry matter basis increased from $15 \mathrm{mM} / \mathrm{g}$ of seeds to $18 \mathrm{mM} / \mathrm{g}$ in expeller cakes produced by a small screw press. However, when calculated on a fat-free dry matter basis, the glucosinolate level in the expeller cakes was close to that in respective seeds. Similar results were reported by Keith and Bell (1991) who found only a very small difference ( 38.4 and $35.8 \mathrm{mM} / \mathrm{g}$ fat-free $\mathrm{DM}$, respectively) between glucosinolate content in seeds and expeller cakes produced from flaked and cooked canola seed.

It may be concluded that pressing has a small effect on glucosinolate level either in cake produced from seeds mildly heated $\left(40-50^{\circ} \mathrm{C}\right)(\mathrm{REM})$ or exposed to higher temperature (REC).

The lack of glucosinolate degradation in seeds heated to over $80^{\circ} \mathrm{C}$ may be explained by the inactivation of myrosinase during the flaking-cooking phase. This is not the case in the expeller cakes produced with the 02 ZVO press where seeds are heated to $40-50^{\circ} \mathrm{C}$ before and to about $75^{\circ} \mathrm{C}$ during pressing. According to Schöne (1995) the main reason of the lack of glucosinolate cleavage in the expelling process is the low water content in the seeds, insufficient for enzyme activity.

In all the cakes, except cake No. 5, the glucosinolate concentration was greater than $15 \mathrm{mM} / \mathrm{g}$ fat-free DM, recommended as the upper limit for solvent extracted rapeseed 00 meal (Krzymański, 1993). A significant reduction of the glucosinolate level in the RSM takes place during desolventizing-toasting, however, the solvent meal used in our study had a very high content of glucosinolates. 
The results of the study indicate that the glucosinolate level in rapeseed 00 expeller cakes produced from mildly heated seeds, and untreated after pressing, depends almost entirely on their content in the seeds. This finding highlights the importance of using the seeds with a very low glucosinolate content for production of press cakes used in animal nutrition.

The energy values of cakes, measured on chickens $\left(\mathrm{AME}_{\mathrm{N}} \mathrm{e}\right)$, varied highly (from 8.5 to $14.60 \mathrm{MJ} / \mathrm{kg} \mathrm{DM}$ ), the fat content being the main factor affecting metabolizable energy value as confirmed by the significant correlation between these two parameters $(r=0.82)$. However, three samples of cakes produced on the 02 ZVO press and having very close fat levels (cake No. 2, 3, and 5) had significantly different $\mathrm{AME}_{\mathrm{\Lambda}} \mathrm{e}$ values $(9.77,11.83$ and $8.55 \mathrm{MJ} / \mathrm{kg} \mathrm{DM}$, respectively) which indicates that some other factors may also be responsible for the variability of energy content. Chibowska et al. (1993) have demonstrated that metabolizable energy value and energy utilization of rapeseed meal is strongly affected by its fibre content. In the present experiment, however, the differences in both crude fibre and ADF and NDF fractions among expeller cakes No. 2, 3 and 5 were too small to explain the differences in $\mathrm{AME}_{\mathrm{N}}$. Crude protein in cakes with lower $\mathrm{AME}_{\mathrm{N}}$ values was less digestible; lower availability of lysine was also found in cake No. 5. It is probable that the temperature during expelling of sample No. 5 may have exceeded $75^{\circ} \mathrm{C}$, which decreases the available lysine content and may make protein less susceptible to enzymatic digestion.

The metabolizable energy values of cakes calculated from their chemical composition were positively correlated with experimental ones, but were less variable.

The $A M E_{\mathrm{N}}$ e value of REM No. 5 was close to the average value for solvent extracted 00 rapeseed meal which is $8.25 \mathrm{MJ} / \mathrm{kg}$ DM according to European Tables of Energy Values for Poultry Feedstuffs (1989) while values for other cakes were substantially higher. Probably due to the short time of feeding in the balance experiment, no correlation was found between digestibility of protein, fat and NFE as well as $\mathrm{AME}_{\mathrm{N}} \mathrm{e}$ values and glucosinolate content in the cakes. However, in a previous experiment (Smulikowska et al., 1990) it was found that increased glucosinolate content in the diet due to substituting rapeseed 00 solvent extracted meal by expeller cake did not affect feed conversion ratio, but caused enlargement of thyroid glands and lower growth rate of broiler chickens.

It may be concluded that feeding rapeseed expeller cake to poultry may be an effective way of increasing the energy concentration of diets, but due to the great variation of fat content, the $\mathrm{AME}_{\mathrm{N}}$ value of cakes should rather be calculated from their chemical composition. More should be known about other factors affecting digestibility of nutrients and energy utilization of expeller cakes.

Total and available lysine contents in expeller cakes were uniform and comparable with respective values found in other studies for seeds and 
pre-pressed cakes from the oil factory, as reported by Keith and Bell (1991) and Grala et al. (1994). These values are considerably higher than usually found in solvent rapeseed meals which may contain as little as 3.5-4.0 g of available lysine/16 $\mathrm{g} \mathrm{N}$ due to the losses occurring during the desolventizing/toasting phase of the process (Mińkowski, 1996). It may be concluded that the pressing technology is less destructive to lysine than solvent extraction and that rapeseed press cake is a better source of this amino acid than RSM.

Despite a uniform lysine content there were large differences between the cakes in the biological value of protein (Table 5 ). Within expeller cakes produced with the 02 ZVO press, REM No. 1 to 4 , BV tended to decrease as the glucosinolate content increased. This relationship could not be extended on the cakes cooked prior to pressing (REC No. 6 and 7) which had considerably greater glucosinolate content than the REM of similar BV.

Lowering the biological value of dietary protein for rats as a result of glucosinolate and myrosinase presence in the diet was reported by Bille et al. (1983) while Raj et al. (1995) found significant depression of protein utilization ( $\mathrm{N}$ retained as \% of digested) in pigs fed on diets balanced in protein and lysine, but containing increasing amounts of glucosinolates from raw 00 rape seeds.

The results of our study indicate a more marked negative response of protein metabolism in rats to glucosinolates from mildly heated seeds than from those heated to over $80^{\circ} \mathrm{C}$, probably due to the higher myrosinase activity in the raw material.

Glucosinolates present in REM negatively affected feed intake, BWG and FCR in rats in a linear, although insignificant, manner. Deterioration of growth performance was accompanied by thyroid hypertrophy, both being characteristic symptoms of feeding rapeseed products containing glucosinolates (for review see Mawson et al., 1994 a,b).

The magnitude of differences of all parameters of nutritional value of protein between the best (No. 1) and the worst (No. 4) REM cake highlights the importance of using rape seeds with a very low glucosinolate content in technology of expelling without cooking .

The expeller cake produced with the Rosedown press from seeds heated to a higher temperature had a very high protein value determined both in balance and growth tests, significantly higher than the cake and solvent meal from the oil factory. It was comparable to that of expeller cake produced using an industrial technology of pressing as described by Nyström et al. (1996).

Although based on a study of limited number of samples, the present results demonstrate great variability of composition and nutritional value of rapeseed expeller cakes produced on 02 ZVO presses. 


\section{REFERENCES}

Bille N., Eggum B.O., Olsen O., Jacobsen I., Sorensen H., 1983. Antinutritional and toxic effects in rats of individual glucosinolates (myrosinases) added to a standard diet. 1. Effects on protein utilization and organ weights. Z. Tierphysiol. Tierernähr. Futtermittelk. 49, 195-210

Booth V. H., 1971. Problems in the determination of FDNB - available lysine. J. Sci. Food Agric. 22, 658-666

Campbell G.L., Campbell L.D., Blair R, 1983. Calculation of metabolizable energy for ingredients incorporated at low levels into a reference diet. Poultry Sci. 62, 705-707

Ekman P., Emanuelson H., Fransson A., 1949. The digestibility of protein in poultry. Kgl. Lantbruks.-Hogskol. Ann. 16, 749

European Table of Energy Value for Pouitry Feedstuffs. 1989. Publ. Group No 2, Nutrition, European Federation WPSA, Beckbergen, The Netherlands

Frankiewicz A., Potkański A., Warych H., Kliber A., Szkudelski T., 1995. Effect of glucosinolate level in the rapeseed cake on production results of young pig (in Polish). Rośliny oleiste-Oil crops 16, 375-381

Grala W., Pastuszewska B., Smulikowska S., Buraczewska L., Gdala J., 1994. Effects of thermal processing on the protein value of double-low rapeseed products. 2. Effect of processing stages in the oil plant and of toasting in laboratory conditions. J. Anim. Feed Sci. 3, 43-55

Hill F.W., Anderson D.L., 1958. Comparison of metabolizable energy and productive determinations with growing chicks. J. Nutr. 64, 587-603

Hinsberg K., Cremer H.D., Schmid G., 1953. In: Hoppe-Seyler/Thierfelder-Handbuch der Physiologisch- and Patologisch-Chemischen Analyse. Springer-Verlag, 5, pp. 402-403

Keith M.O., Bell J.M., 1991. Composition and digestibilty of canola press cake as a feedstuff for use in swine diets. Can. J. Anim. Sci. 71, 879-885

Kinal S., Jaroš L., Friť Z., Schleicher A., 1990. Use of cake and solvent meal from rapeseed of double low varieties in the diets for broilers (in Polish). Biul. inf. Przem. Pasz. 3, 51-59

Krzymaniski J., 1993. Possibility to take the full advantages of the quality of doublc low oilseed rape (in Polish). Post. Nauk. ro!. 6, 161-166

Lehman H., Hock A., Bergner H., 1968. Bestimmung des N-Erhaltungsbedarfes von Albinoratten. Arch. Tierernähr. 18, 280-291

Mawson R., Heaney R. K., Zduńczyk Z., Kozłowska H.,1994a. Rapeseed meal-glucosinolates and their antinutritional effects Part 3. Animal growth and performance. Nahrung 38, 167-177

Mawson R., Hcancy R.K., Zduńczyk Z., Kozłowska H., 1994b. Rapeseed meal-glucosinolates and their antinutritional effects. Part 4. Goitrogenicity and internal organs abnormalities in animals. Nahrung 38, 178-191

Mińkowski K., 1996. Optimalization of parameters of treatment of rapesecd meal in a toaster in the aspect of maintenance of the maximum amount of available lysine (in Polish). Annales of the Institute of Mcat and Fat Industry (in press)

Pesti G.M., Ware G.O., 1986. Expressing the variability in results of metabolizable energy assays. J. Nutr. 116, 1385-1389

Podkówka W., Podkówka Z., 1993. Nutritive value of rapeseed cake obtaincd by the usc of screw press 02 PVO (in Polish). Post. Nauk. rol. 6, 177-180

Podkówka W., Podkówka Z., Doroszewski P., 1994. Nutritive value of rapeseed cake obtained by the use of screw press 02 PVO (in Polish). Rośliny oleiste - Oil Crops 15, 179-182

Polish Standard (Norma 1SO-9167-1), 1991. HPLC method of glucosinolates determination (in Polish) 
Raj S., Kotarbinska M., Fandrejewski H., Chabiera K., 1995. The efficiency of energy and protein utilization by growing pigs fed diets containing both full-fat rape seeds and rapeseeds meal. $\mathbf{J}$. Anim. Feed Sci. 4, 107.117

Rakowska M., Ochodzki P., 1995. Chemical and biological evaluation of rapeseed meals derived from 5 countries, obtained with different processing procedures. Procecdings of 9 th International Rapeseed Congress: Rapeseed today and tomorrow. Cambridge, pp. 203-205

Schöne F., 1996. Rapeseed acceptability to pigs. Feed Mix 4, 29-32

Smulikowska S., Chibowska M., Wiśniewska J., 1990. Effects of low glucosinolate rape seed-raw, pressed or extracted on performance, thyroid status and fatty acid profile of broiler chicken. Proceedings of 8th European Poultry Conference, Barcelona, pp. 348-351

Tywończuk J., Lipinski K., Flis M., Sobotka W., 1994. Rapeseed cake in the feeding of growing-finishing pigs (in Polish). Proceedings of 24th Conference on Recent Advances in Pig Nutrition, pp. 156-158

Van Soest P.J., 1967. Use of detergent in the analysis of fibrous feeds. IV. Determination of plant cell-wall constituents. J. Assoc. Off. Agric. Chem. 50, 50-55

\section{STRESZCZENIE}

Skład chemiczny oraz wykorzystanie energii i bialka wytłoków rzepakowych wyprodukowanych przy zastosowaniu różnej technologii

Oznaczono skład chemiczny, zawartość glukozynolanów oraz lizyny ogólnej i dostẹpnej w siedmiu próbach wytloków rzepaku ,00" i jednej próbie śruty poekstracyjnej. Pięć prób wytloków wyprodukowano za pomoca prasy 02 ZVO z nasion ogrzewanych do $40-50^{\circ} \mathrm{C}$ (REM), jeden za pomocą prasy Rosedown $z$ nasion ogrzewanych w temperaturze powyzej $80^{\circ} \mathrm{C}$ (REC No. 6), a jeden pochodził 7 przemysłowego przerobu nasion ogrzewanych w temperaturze powyżej $80^{\circ} \mathrm{C}$ w olejarni (REC No. 7) Zawartość tłuszczu w wytlokach wynosila od 10,3 do $23,2 \%$ s.m., glukozynolanów od 13,4 do $55,1 \mathrm{mM} / \mathrm{g}$ beztluszczowej s.m. i była 7bliżona do zawartości w surowych nasionach.

O/naczona na kurczętach wartość energetyczna $\left(\mathrm{AME}_{\mathrm{N}}\right)$ wytloków REM i REC No. 7 byla bardzo zróżnicowana (od 8,55 do $14,60 \mathrm{MJ} / \mathrm{kg} \mathrm{SM}$ ) i skolerowana dodatnio z zawartością tluszczu. Biologiczna wartość (BV) bialka czterech prób wytłoków REM, dwóch REC i śruty poekstrakcyjnej, oznaczona na szczurach, była różna i wynosiła od 80,1 do 96,7, mimo zbliżonej zawartości lizyny ogólnej i dostępnej. U szczurów otrzymujących wytloki REM wystąpiła tendencja do obniżania sję BV, pobrania paszy i przyrostów masy ciała, natomiast do 7większania się wrględnej masy tarczycy w miarę wzrostu zawartości glukozynolanów w diecie.

Otrzymane wyniki pozwalają na wyciąnnięcie wniosku, że wartość pokarmowa wytloków wyprodukowanych $\ell$ nasion ogrzewanych $w$ niskicj temperaturze moźc być bardzo zróżnicowana. Głównym czynnikiem wpływającym na wartość energetyčną wylloków jest zawartość tłuszc\%u, a na wyk orrystanie białka - zawartość glukozynolanów. 